opinion. There is no question that this atlas will be the definitive resource on its subject for some years to come. Atlas developers will find that the editors make use of best practices in cartographic technique and data visualization, but also employ many innovative approaches to display of complex information in its pages. The atlas also includes an index, bibliography with an extensive list of key documents, books, and scholarly articles, and a glossary to ensure that readers with limited familiarity with the LDS and its traditions can understand the usage and meaning of common terms such as elder, pioneer, auxiliary, and stake.

Mapping Mormonism should be added to geography and map library holdings focusing on the North American continent and will also be of interest internationally. Those interested in the cultural historical geography of the American West should also consider adding it to their professional libraries. Aficionados of fine examples of data visualization will also find Mapping Mormonism a delightful read that they may wish to refer to from time to time.

\title{
SECRET SCIENCE: SPANISH COSMOGRAPHY AND THE NEW WORLD
}

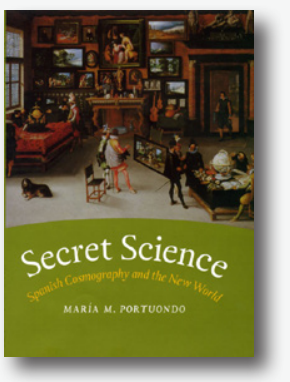

By Maria M. Portuondo.

The University of Chicago Press, 2013.

335 pages, 18 figures, 10 color plates, 7 maps, 5 tables. $\$ 60.00$, Softcover.

ISBN 978-0-226-67534-3

Review by: Maria Martin, Michigan State University

During the Age of Discovery in the 15th century, European nations expanded their hegemony into the New World. In this time of colonization and exploitation, many reconnaissance missions were dispatched to collect information on the topography of the land, its resources, and the cultures there. The field of cosmography was born out of the demand for tangible and detailed representations of these newly acquired lands. Maria M. Portuondo, in Secret Science: Spanish Cosmography and the New World, argues that the Spanish, during the reigns of Charles V, Phillip II, and Phillip III of the Habsburg monarchy, made significant contributions to the science of map making.

Portuondo asserts that the Spanish had a significant impact on the development of cosmographic theory and practice. However, in an attempt to protect their interests and possessions in the New World, Philip II treated map making as a state secret: "the work of royal cosmographers was science with a mission, deployed solely for the benefit of the state" (3). Cosmographers were not allowed to publish any of their projects on the New World for fear of the information falling into the hands of enemies and rivals who wished to attack and acquire Spanish lands. This prohibition created a period of silence in Spanish scientific knowledge production which came to be interpreted as a Spanish proclivity toward humanistic rather than scientific pursuits. Portuondo, through analysis of lectures and curricula from the University of Salamanca, state documents from the Casa de Contratación (House of Trade) and the Council of the Indies, as well as the works of contemporary Spanish intellectuals investigates the silence to explore the ways in which the Spanish actually refined the field of cosmography.

Secret Science consists of seven chapters. The first chapter traces the intellectual development of Spanish cosmography as professors at the University of Salamanca led critiques of, and found innovative ways to apply, classical texts such as Ptolemy's Geographia, Pomponius Mela's De Situ Orbis, Pliny's Historia Naturalis, and Sacrobosco's Sphere. Their research informed the development of navigation books. The second chapter speaks to the growth of cosmographic practice in the state-run agencies of the Council of Indies and the Casa de la Contratación. New discoveries were constantly made and so previous methods of cosmographic representation quickly became outdated. Philip II's royal cosmographer Alonzo de Santa Cruz and scientific advisor Juan de Herrera addressed these inadequacies through illustrations based on humanistic and mathematical interpretations, respectively. Chapter three discusses the codification and confidentiality of map making. In the early 16th century, the Council of the Indies sought to keep confidential the location of strategic Spanish ports in the New World and legal scholar-priest Juan de Ovando y Godoy developed a standard format for cosmographic descriptions. 
The fourth highlights the work of Juan López de Velasco, which was the first official cosmography of the Indies that followed the rules set by Ovando. The fifth chapter examines and critiques two of Velasco's major works. The sixth considers the development and implementation of the use of questionnaires and observation of lunar eclipses. The surveys helped to organize the cosmographic data/ descriptions that explorers sent to state agencies, while the eclipses helped the explorers to determine their longitude. The seventh and final chapter describes the change in attitudes about cosmographic secrecy from the reign of Philip II to his son Philip III, who made the information public. At this time there was also a split in the office of royal cosmographer, into one position that focused solely on mathematical interpretations and one that concentrated on descriptive ethnography and natural history.

Portuondo identifies four main objectives for Secret Science. First, she seeks to argue that the Spanish did in fact have an interest in scientific, not solely humanistic, knowledge production. Second, to clarify that the Spanish made important developments in the field of cosmography. Third, to demonstrate that early methods of map making involved a dialogue, not a separation, between the physical and social sciences. Fourth, to give a "new perspective of the historical narrative of the Scientific Revolution on how practitioners of Western science responded to the new world" (16).

She achieves her first, second, and third objectives through her account of the humanismo cientifico (scientific humanism) movement, begun by professors at Salamanca. Portuondo establishes that from an early date Spanish intellectuals used physical sciences in conjunction with social sciences. Professors Ciruelo and Nebrija worked together to build a curriculum that would teach students how to incorporate a mixed method into cosmographic science. Their framework was used to develop a navigation book that was accessible to non-academics, by utilizing a narrative style to explain mathematical and astronomical concepts important to sailors. The bumanismo cientifico and development of navigation books are evidence of both the presence of a scientific tradition in Spanish cosmography and their unique contribution to the field.

Portuondo goes on to further support objectives one through three by debunking the myth of Spanish disinterest in the sciences. This untruth developed as a result of the lack of publication of the innovative work done at the Casa de la Contratación and the Council of the Indies by royal cosmographers and scientific advisors, and other intellectuals. Philip II placed restrictions on authorship, publishing, and sales, controlled access to primary sources that informed map makers, and placed a ban on books that contained information about the conquest and colonization of the New World. Portuondo states: "The censorship policy was formalized on September 21, 1556, prohibiting the printing and sale of any book that dealt with the subject of the Indies before it had been seen or examined by the Council of the Indies. Local authorities were instructed to inform the Council about such books and could be directed to seize them" (105). This secrecy became a legal mandate: "When during the 1570 s a legal code Ordenanzas de Indias (1571) came into effect that institutionalized cosmographical practice at the Council of the Indies, these standing secrecy and censorship policies limiting the diffusion of historical, geographical, and natural historical information about the New World became law" (107).

The monopoly that the crown had on the flow of cosmographic information prohibited intellectuals from sharing knowledge and making contributions to the broader scientific canon. Even so, the development of a legal code prompted Ovando to conduct a meticulous audit of the "spiritual, financial, and political governance of the Indies" (116). He conducted meticulous interviews with clergymen, businessmen, and colonists and compiled and revised the laws, royal orders, and edicts that had been released since the Age of Exploration began. With this information he produced Recopilación de leyes de Indias as a means of meeting the need for cogent laws and a standard cosmographic structure. The legal reformation of Ovando supports Portuondo's contention that the Spanish did develop original methods and paradigms that informed cosmographic practice. Ovando's work also further exemplifies that combination of humanistic and scientific methods that was characteristic of early Spanish cosmography. Likewise, her investigation of the secrecy of Philip II establishes that Spanish were indeed concerned with scientific knowledge production but that it was kept confidential for the protection of the state.

Portuondo reaches her fourth objective, to develop a new narrative within the literature on the Scientific Revolution, by uncovering and analyzing Spanish cosmography projects and their significance to the scientific intellectual tradition of the Renaissance period. The Age 
of Discovery was a pivotal time in cosmographic history because it signaled a transformation in scientific perspectives and methods in an attempt to understand the New World. According to Portuondo: "Nowhere was the determination to create a framework to explain the reality of the New World more steadfast than in sixteenth-century Spain. Spanish cosmographers brought to their discipline alternative epistemologies and new methodologies that eventually changed how Europeans saw the natural world" (1-2).

Her work is situated in the historic debate Portuondo calls the "polemics of Spanish science." Within this discourse she suggests that contemporary definitions of science place a staunch separation between the hard and social sciences; however the history of Spanish cosmography problematizes this notion of separation. The author also posits that this more stringent definition of science inherently excludes the work of those that combined the hard and social sciences. In order to highlight Spanish scientific traditions she defines science with more fluidity. This allows her to permeate the text with rich examples of the continuity between the hard and social sciences which characterizes a major era in Spanish cosmographic development.
Secret Science is a thoroughly researched and valuable resource that identifies the importance of returning to those progenitors of overseas exploration to really understand the development of cosmography and the origins of the Scientific Revolution. Portuondo presents adequate evidence to support her contention that Spaniards developed important, original, and innovative theories and practical methods in the field of cosmography as a function of their imperial goals. However, it does seem that her sources are reflective of the elite perspective and the voices of the nonelite do not receive as much attention. It would have been very interesting and refreshing, for example, to have included more in-depth discussion about the ways in which commoners (who were experienced sailors and colonists) contributed to the development of navigation books and cosmographies. Nonetheless, Secret Science is important in that it debunks the myth of Spanish disinterest in science and helps one to rethink the narrative of the Scientific Revolution through revisiting the Age of Discovery. In doing so it also enforces the notion that historical perceptions of science were more fluid and combined the hard and social sciences. Thus historical scientific methods cannot be judged by the rigid contemporary definitions of science. As Portuondo proves, this could exclude important periods and developments from further insightful analysis and consideration in the scientific canon. 